Vol 3. No 1. February 2019

ISSN 2580-5029

\title{
TAXONOMY OF CRUSTOSE LICHENS IN THE FOREST OF TAHURA R. SOERYO, BATU, EAST JAVA
}

\author{
Miftahul Jannah', Ludmilla Fitri Untari² \\ ${ }^{1}$ Universitas Islam As-syafi iyah, Jakarta, Indonesia \\ 2 Universitas Gadjah Mada, Yogyakarta, Indonesia \\ *mifta_frozi@yahoo.com
}

\begin{abstract}
Lichen is a symbiotic organism consisting of a photobiont (green algae or cyanobacterium) and a mycobiont (fungal). A taxonomic study of the crustose lichens in the forest of TAHURA $R$. Soeryohad been conducted based on morphological, anatomical, and chemical characters. In this research we used the method of descriptive exploration to identify the crustose lichens and to study the distribution of the species in the forest of TAHURA R. Soeryo. Twenty species of crustose lichens with one unidentified species and one specimen identified to the group of family are reported. They are Graphina, Graphis, Phaeographis, Pertusaria, Pachyphiale, Phlyctis, Lepraria, Lecanora, Lecania, Cyphellium, and Megalospora. This research also found the new record species of Megalospora kalbii in Java. Crustose lichens are found in the areas with high light intensity of $\geq$ 1000 lux, average humidity of $\leq 90 \%$, average temperature of $18-19^{\circ} \mathrm{C}$, and at altitudes of \pm 1640 $\mathrm{dpl}$. Graphina ruiziana could only be found at the altitude of $\pm 1780 \mathrm{dpl}$. The identification key to its species and distributions of other species are presented also in the article.
\end{abstract}

Key words: Diversity, Crustose Lichen, Forest of Tahura R. Soeryo

\section{INTRODUCTION}

Everyone is familiar with plants as green chlorophyll- containing organisms that produce their own food. Lichens are also a plant, but a very special kind, for when we dissect and examine it under a microscope, we find that it is composed of two completely different organisms, microscopic green or blue-green algae and colorless fungal threads called hype. These two components grow together in a harmonious association referred to as symbiosis, or more simply a "living.together". Lichen symbiosis, however, differs basically from all other kinds in that a new plant body, the thallus, is formed and this talus has no resemblance at all to either a fungus or alga growing alone (Hale, 1969). Lichens can be found from extreme low tide level on the sea-shore to the tops of high mountains, and from arctic to tropical regions (Dobson, 1992).

Growth form means the overall shape and configuration of the lichen talus. There are three major types: foliose, fruticose, and crustoce (Hale, 1974; Rout et.al., 2010). A fourth type, the squamulose lichens, may also be recognized. The whole association grows at a rate ranging from one millimetre or less 
per year for crust (crustose) lichens up to a few centimetres a year for the most rapidly growing leafy (foliose) or shrubby (fruticose) lichens (Richardson, 1992). The distribution of lichens is governed by many interacting factor i.e. topography, substrate, light intensity, moisture, humidity (Termina et.al., 2009; Ramakantha et.al., 2003; Hayward et.al., 1975; Kenkel et.al., 1986 ) and altitude (Hayward et.al., 1975).

Tropical forest has a complex component either flora or fauna. One of the tropical forests in Indonesia is an Arjuno Lalijiwo forest which is more famous with Taman Hutan Raya R.Soeryo (TAHURA). Geographically, Tahura is located in Tulungrejo village, Bumiaji District, East Java. Topography in general has various configurations among superficial, hilly, mountain with 1000-3000 m high from the upper surface of sea shore. Its altitude is $1000-3000 \mathrm{~m}$, the rainfall is about $2500-4500$ $\mathrm{mm}$ per year, and the temperature is about ${ }^{\circ} \mathrm{C}-10^{\circ} \mathrm{C}$. Biotic potential of that area is flora condition dominated various kinds of plant. (Departemen Kehutanan, 2008). Deforestation is a major enviromental issue which may cause disappearance of many lichen species without being studied. Fifteen species of foliose lichen (Jannah et.al., 2009) and eleven species of fruticose lichen (Jannah et.al., 2011) is reported in this forest.

Lichens has a big diversity in this world, however, people pay very small attention in this subject. Lichens play a very important role in the ecosystem, as oxygen supplier, bioindicator of air pollution and air quality biomonitoring (Richardson, 1992; Negi, 2003; Eva, 2003; Rout et.al., 2010). This rich diversity indicates good forest health. Lichens can also be very usefull,as medicine, antibiotic, antimutagenic, cosmetic (Nash, 1996; Negi, 2003) and pesticide (Dayan et.al.,2001).

Therefore, we had conducted a lichen taxonomical research in purpose to study the diversity of crustose lichens in TAHURA R.SOERYO, to identify the species of lichen in the TAHURA R. Soeryo, and to provide the identification key of its species, in which the study would support the conservation of lichen in situ in the ecosystem.

\section{METHODS}

This research is descriptive explorative which has purpose to study the diversity of crustose lichens in TAHURA R. Soeryo. This researches was conducted from September - January 2015, in which involved a method of descriptive explorative technique. The identification involved the method of determining the shape and colour of the thallus, the presence or absence of soredia, soralia, and isidia and the size and septation of the spores within the fruit bodies and chemical tested. The chemical substances used are P (Phenylenediamin), K (Potassium hydroxide), and C (Calcium hypoclorite). The substances of thallus lichen are identified by their characteristic microcrystal formation in various reagents i.e. GAW $\left(\mathrm{H}_{2} \mathrm{O}\right.$ : glycerol: ethanol $=1: 1: 1)$, GE (acetic acid $:$ glycerol $=$ 
1:3), An (aniline : glycerol : ethanol = 1:2:2), dan oT ( o-toluidine : glycerol : ethanol = $1: 2: 2)$.

\section{RESULTS AND DISCUSSION}

The diversity of crustose lichen in the forest of TAHURA R. Soeryo, Batu, East Java consist of 9 families and 20 species of crustose lichen with one species unidentified and one specimen identified to the group of family. In this research the family Graphidaceae is the most common with 8 species being identified. This research is expected to be a preliminary study for further research such as in depth study of lichen diversity or genetic relation.

\section{Identification Key}

1. a. Soralia

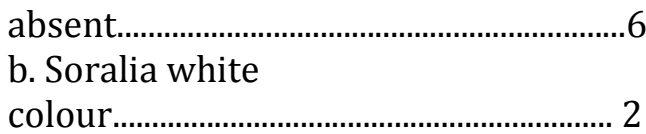

2. a. Soredia whit colour(P+red,
$\mathrm{K}-)$. Pertusaria amara
b.Sorediaabsent. ...3

3. a. Isidia absent (K+yellow, $\mathrm{P}+\mathrm{red}$, C+yellow). Unidentified

b. Isidia white colour. 4

4. a. Soredia absent (K-, P-.
C-). Pertusaria corallina
b. Soredia green colour 5

5. a. Isidia reddish yellow colour $(\mathrm{K}+\mathrm{red}$, P+red, C+yellow) Lepraria sp.

b. Isidia green $(\mathrm{K}+\mathrm{red}, \mathrm{P}+\mathrm{red}$,
C-). Pertusaria sp.

6. a. Lirellate apothecia. .15

b. Disc apothecia 7

7. a. Margin and disc of apothecia cant be differentiated...................ecania cyrtella b. Margin and disc of apothecia can be differentiated. . .8

8. a. Spore one septate with epispore warted (K+yellow) campylospora

b. Spore one septate with epispore smooth.
9. a. Apothecia margin greyish white $(\mathrm{K}+$ yellow,P+red).......Cyphellium inquinans b. Apothecia margin reddish orange. .10

10.a. Spore muriform, $\geq 2$ in each ascus $(\mathrm{K}+\mathrm{red}, \mathrm{C}+$ yellow)..........Phlyctis agelaea b. Spore muriform, one in each ascus. .11

11. a. Apothecia green pruinose
( $\mathrm{P}+$ reddish yellow) kalbii Megalospora

b. Apothecia epruinose.

12. a. Spora multiseptate, $2-40$ in each ascus

(K+yellow) Pachyphiale carneola

b. Spora multiseptate, one in each ascus. 13

13. a. Apothecia with reddish brown disc (K-, C-, P-)..................Pachyphiale sp.

b. Apothecia with dark brown disc....14

14. a. Apothecia lecideine (K+yellow, $\mathrm{C}$ $\mathrm{P}+\mathrm{red})$...........Megalospora $\mathrm{cf}$. sulphurata b. Apothecia lecanorine $(\mathrm{K}+\mathrm{yellow}, \mathrm{P}+\mathrm{red}$, C+yellow)..............ecanora carpinea

15. a. Margin and centre of apothecia can be differentiated ( $\mathrm{K}+$ kuning, C+kuning) Graphidaceae

b. Margin and centre of apothecia cant be differentiated .16

16. a. Lirellae innate $(\mathrm{P}+\mathrm{red}$, C+yellow) Graphina anguina

b. Lirellae elevate .17

17. a. Apothecia rarely branched (K+yellow) ...Graphina ruiziana

b. Apothechia much branched 18

18. a. Apothecia white pruinose

(K+yellow) Graphina columbina

b. Apothecia brown pruinose. 19

19. a. Spore multiseptate with thick-walled (K+yellow).............Phaeographis lyelli b. Spore multiseptate with thin-walled. 20

20. a. Margins of lirellae with several furrows, often $(\mathrm{K}+\mathrm{red}) . . . . . . . . . . . . . . G r a p h i s ~ e l e g a n s$

b. Margins of lirellae unfurrowed......21

21. a. Lirellae with dull black (P+red, C+yellow) Graphis scripta

b. Lirellae with pale brown (K+red,C+yellow). ..Graphis glaucescens 
Taxonomic Descriptions

Graphina anguina (Mont.) Müll. Arg.

This lichen belongs to Graphidaceae family. Thallus grey, irregularly shaped, usually wrinkled and cracked; chemistry: 40 -methylphysodic acid, roccellaric acid, and acetylportentol; apothecia lecideine, immersed, lirellate innate, margins with gray, centre with black, much branched and serpentine; spores 2-8 in each ascus, colourless, muriform, $1,5-2 \quad$ x $1-2 \mu \mathrm{m}$; Chemical test in medulla are C+yellow, $\mathrm{K}$-, P+red. Habitat and ecology: In forest, this species was found on old and cracked bark, at altitudes ranging from 1640-1730 dpl, temperature is about $16^{\circ}-19^{\circ} \mathrm{C}$, humidity is about $83-98 \%$, and light intensity is about 475-1700 lux.

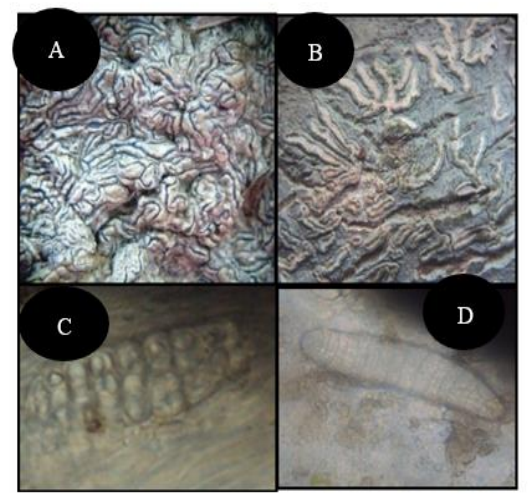

Figure 1. Thallus. A. G. anguina; B. $G$. columbina; Spores. C. G. anguina; D. G. columbina

\section{Graphina columbina (Tuck.) Wirth et.} Hale. Jr.

This lichen belongs to Graphidaceae family. Thallus greenish to brownish, irregularly shaped; chemistry: dissectic acid with atranorin, fumarprotocetraric acid, acetylportentol, barbatic acid, and retigeric acid; apothecia lecideine, lirellate, margins with pale green, centre with white and widely, white pruinose, much branched; spores 2-8 in each ascus, colourless, muriform, 6-15 x 1-3 $\mu \mathrm{m}$; Chemical test in medulla are $\mathrm{C}-, \mathrm{K}+$ yellow, $\mathrm{P}-$ . Habitat and ecology: In forest, this species was found on old and cracked bark, at altitudes ranging from 1640-1780 dpl, temperature is about $17,5-19^{\circ} \mathrm{C}$, humidity is about $85-98 \%$, and light intensity is about 600-1150 lux.

\section{Graphina ruiziana (Fée) Müll. Arg.}

This lichen belongs to Graphidaceae family. Thallus greenish grey or whitish, irregularly shaped, sometimes scarcely developed, it has orange soredia; chemistry: dissectic acid with atranorin, 4-0methylphysodic acid, acetylportentol, and retigeric acid; apothecia lecideine, lirellate, margins with whitish grey, centre with black, elevated, and rarely branched (unbranched); spores $>1$ in each ascus, colourless, muriform, 6-12 x 1-2 $\mu \mathrm{m}$; Chemical test in medulla are C-, K+yellow, P-. Habitat and ecology: In forest, this species was found on old and cracked bark, at altitudes ranging from $1780 \mathrm{dpl}$, temperature is about $17,5^{\circ} \mathrm{C}$, humidity is about $98 \%$, and light intensity is about 600 lux.

\section{Graphis galucescens Wirth et. Hale. Jr.}

This lichen belongs to Graphidaceae family. Thallus white to greenish grey, irregularly shaped; chemistry: fumarprotocetraric acid, bellidiflorin, 
nephroarctin, dan pseudo-norrangiformic acid; apothecia lecideine, lirellate, margins with greenish grey, centre with pale brown, spiral and much branched; spores 4-) 6 (8- in each ascus, colourless, multiseptate, 4-6 x 1 $\mu \mathrm{m}$; Chemical test in medulla are C+yellow, K+red, P+red. Habitat and ecology: In forest, this species was found on old and cracked bark, at altitudes ranging from $1780 \mathrm{dpl}$, temperature is about $17,5^{\circ} \mathrm{C}$, humidity is about $98 \%$, and light intensity is about 600 lux.

\section{Graphis elegans (Sm.) Ach.}

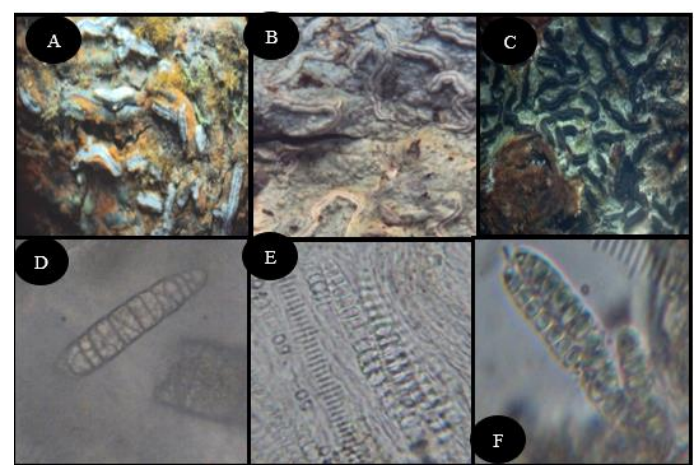

Figure 2. Thallus. A. G. ruiziana; B. G. galucescens; C. G. elegans; Spores. D. G. ruiziana; E. G. galucescens; F. G. elegans.

This lichen belongs to Graphidaceae family. Thallus greenish grey, irregularly shaped, smooth, rather thin, slightly, and wrinkled; chemistry: barbatic acid and acetylportentol; apothecia lecideine, lirellate, margins with black and several furrows, centre with black, spiral and carbonaceous; spores 6-13 in each ascus, colourless, multiseptate, $5 \times$ x $0,5-1 \mu \mathrm{m}$; Chemical test in medulla are C+yellow,
K+red, P+red. Habitat and ecology: In forest, this species was found on old and cracked bark, at altitudes ranging from 1640-1800 $\mathrm{dpl}$, temperature is about $17,5^{\circ}-19^{\circ} \mathrm{C}$, humidity is about $85-98 \%$, and light intensity is about $600-1700$ lux.

\section{Graphis scripta (L.) Ach.}

This lichen belongs to Graphidaceae family. Thallus grey, smooth or wrinkled, irregularly shaped; chemistry: 4-0methylphysodic acid and acetylportentol; apothecia lecideine, lirellate, margins with gray and unfurrowed, centre with pale black, sometimes pruinose and carbonaceous; spores 11-15 in each ascus, colourless, multiseptate, 4-5 x 0,5-1 $\mu \mathrm{m}$; Chemical test in medulla are C+yellow, K-, P+red. Habitat and ecology: In forest, this species was found on old and cracked bark, at altitudes ranging from $1640-1730 \mathrm{dpl}$, temperature is about $16^{\circ}-19^{\circ} \mathrm{C}$, humidity is about $85-98 \%$, and light intensity is about 475-1150 lux.

\section{Phaeographis lyelli (Sm. ) Zahlbr.}

This lichen belongs to Graphidaceae family. Thallus green, smooth, glossy, irregularly shaped; chemistry: thamnolic acid with decarboxythamnolic acid, acetylportentol, nephroarctin, and $\alpha$ acetylsalazinic acid; apothecia lecanorine, lirellate, margins with green, centre with brown; spores $>3$ in each ascus, colourless, multiseptate, $3-4 \times 1 \mu \mathrm{m}$; Chemical test in medulla are C-, K+yellow, P+red. Habitat and ecology: In forest, this species was found on old and cracked bark, at altitudes ranging from $1640 \mathrm{dpl}$, temperature is about $18,5^{\circ}$ - 
$19^{\circ} \mathrm{C}$, humidity is about $83-85 \%$, and light intensity is about 1050-1150 lux.

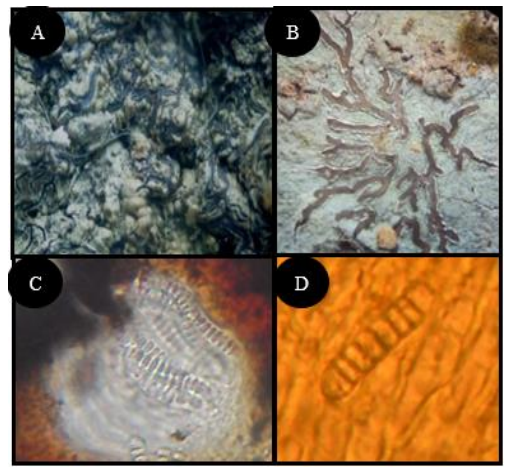

Figure 3. Thallus. A. G. scripta; B. P. lyelli; Spores. C. G. scripta; D. P. Lyelli.

\section{Graphidaceae}

This lichen belongs to

Graphidaceae family. Thallus brwonish gray, smooth, irregularly shaped, it has yellowish white soredia; chemistry: 4-0methylphysodic acid, acetylportentol, and pseudo-norrangiformic acid; apothecia lirellate, elevated, unbranched; Chemical test in medulla are C+yellow, K+yellow, P-.

Habitat and ecology: In forest, this species was found on old and cracked bark, at altitudes ranging from $1640 \mathrm{dpl}$, temperature is about $18^{\circ}-19^{\circ} \mathrm{C}$, humidity is about $75-85 \%$, and light intensity is about 1050-1700 lux.

Notes: Identification of this species is only to family, because of no spores was found on the surface of the talus. Spore type is a very important aspect for identification as a special characteristic of a species and genus (Dobson, 1992).

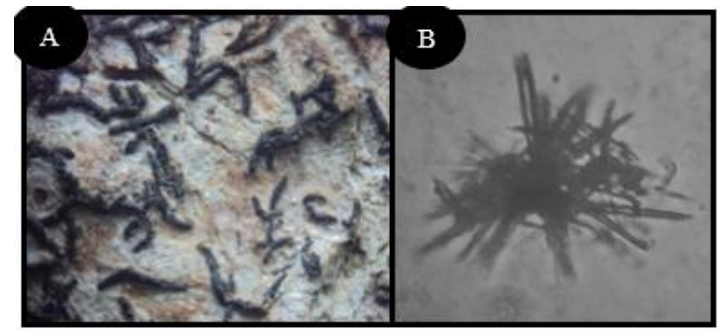

Figure 4. Graphidaceae. A. Thallus; B. 4-0methylphysodic acid.

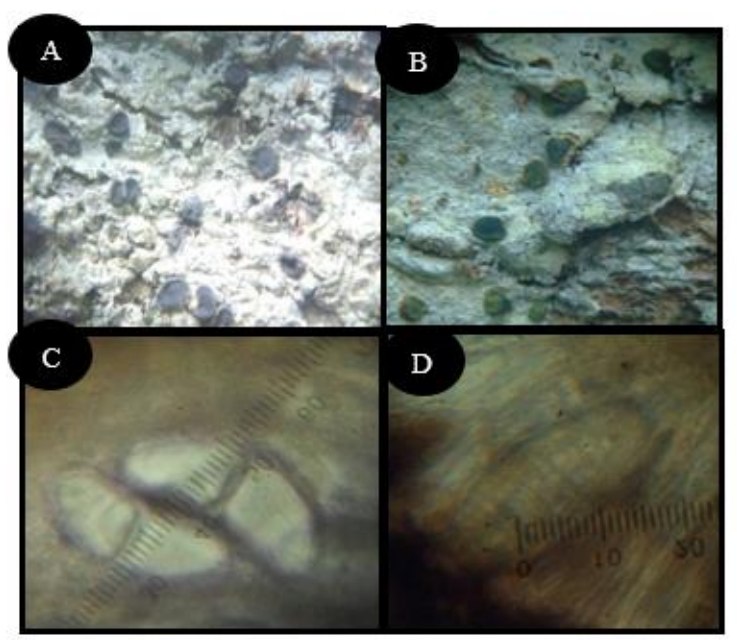

Figure 5. Thallus. A. M. campylospora; B. M. kalbii; Spores. C. M. campylospora; D. M. Kalbii.

Megalospora campylospora (Stirt.) Sipman

This lichen belongs to egalosporaceae family. Thallus greenish gray, irregularly shaped, rather thick, very rugulose with little cracks; chemistry: diffractaic acid and acetylportentol.; apothecia lecidine, scattered, sessile, orbicular or oblong and the large ones becoming lobed to reniform to irregularly shaped, margins with black, disc with black, up to $3 \mathrm{~mm}$ diam; spores 4-6 in each ascus, colourless, one septate with epispore warted, 10-25 x 20-28 $\mu$; Chemical test in medulla 
are C+yellow, K+yellow, P+red. Habitat and ecology: In forest, this species was found on old and cracked bark, at altitudes ranging from 1640-1800 dpl, temperature is about $16^{\circ}-18,5^{\circ} \mathrm{C}$, humidity is about $75-98 \%$, and light intensity is about 45-1700 lux.

\section{Megalospora cf. sulphurata Meyen}

This lichen belongs to Megalosporaceae family. Thallus greenish gray, irregularly shaped, rather thin to rather thick, smooth to very rugulose, small cracks or with longitudinal, epruinose; chemistry: diffractaic acid, haemathamnolic acid, barbatic acid dan acetylportentol.; apothecia lecidine, scattered, sessile, orbicular to oblong and the large ones becoming lobed or irregularly shaped, margins with black, disc with brown to black, up to $3 \mathrm{~mm}$ diam; Chemical test in medulla are $\mathrm{C}-, \mathrm{K}+$ yellow, P+red. Habitat and ecology: In forest, this species was found on old and cracked bark, at altitudes ranging from $1640 \mathrm{dpl}$, temperature is about $18,5^{\circ}-19^{\circ} \mathrm{C}$, humidity is about 83 $85 \%$, and light intensity is about $1050-1150$ lux.

Notes: In this species, further identification is still needed, because at the time of the identification process there were no spores found in all the apothecia in the talus. This species is identified as Megalospora genus, because has special characteristics of dark colored apothecia, between the margin and the disc can be clearly distinguished, there is oildroplet in the himenium (Sipman, 1983).

\section{Megalospora kalbii Sipman}

This lichen belongs to Megalosporaceae family. Thallus grayish white, irregularly shaped, rather thin to rather thick, smooth to very rugulose, epruinose; chemistry: 4-0-methylphysodic acid and acetylportentol; apothecia lecidine, scattered, adnate, orbicular to oblong and the large ones becoming lobed or irregularly shaped, margins with black, disc with brown to black, dull green pruinose, up to $1 \mathrm{~mm}$ diam; spores one in each ascus, colourless, muriform, 10-15 x 20-50 $\mu \mathrm{m}$; Chemical test in medulla are C-, K-, P+red. Habitat and ecology: In forest, this species was found on old and cracked bark, at altitudes ranging from $1640 \mathrm{dpl}$, temperature is about $18^{\circ}$ $18,5^{\circ} \mathrm{C}$, humidity is about $75-83 \%$, and light intensity is about 1050-1700 lux.

Notes: This species in Sipman (1983) states that having a brown or dark color apothecia and there is no pruina, whereas in the Sipman (1999) online identification key, it is written that this species has a pale brown to brownish and white pruina on the disc. The species found in the Cangar Forest are dark colored (dark green) and pruina is dark green.

\section{Pertusaria amara (Ach.) Nyl.}

This lichen belongs to

Pertusariaceae family. Thallus grayish white, irregularly shaped, thick and delimited, it has white soredia and soralia, very bitter taste of the soralia; chemistry: baeomycesic acid, 40-methylphysodic acid and acetylportentol; 
Chemical test in medulla are $\mathrm{C}-, \mathrm{K}-, \mathrm{P}+\mathrm{red}$. Habitat and ecology: In forest, this species was found on old and cracked bark, at altitudes ranging from $1640 \mathrm{dpl}$, temperature is about $18^{\circ}-18,5^{\circ} \mathrm{C}$, humidity is about $83 \%$, and light intensity is about 1050-11650 lux.

\section{Pertusaria corallina (L.) Arn.}

This lichen belongs to Pertusariaceae family. Thallus white to pale gray, irregularly shaped, thick, warted, it has white isidia; chemistry: fumarprotocetraric acid, pseudo-norrangiformic acid, hiascic acid, and acetylportentol; Chemical test in medulla are C-, K-, P-. Habitat and ecology: In forest, this species was found on old and cracked bark, at altitudes ranging from 1640 $\mathrm{dpl}$, temperature is about $18,5^{\circ}-19^{\circ} \mathrm{C}$, humidity is about $83-85 \%$, and light intensity is about $1050-1150$ lux.

Notes: This species was found in the stone (Dobson, 1992).

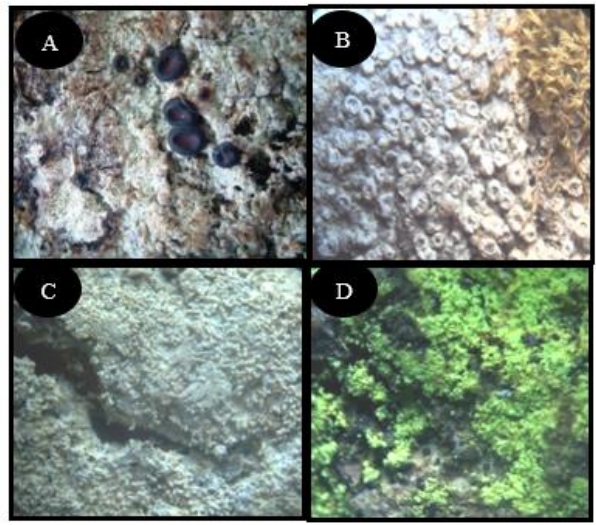

Figure 6. Thallus. A. M. cf. sulphurata; B. P. amara, C. P. corallina, D. Pertusaria sp.

\section{Pertusaria sp.}

This lichen belongs to Pertusariaceae family. Thallus gray, irregularly shaped, thick, warted, it has green soredia and isidia; chemistry: dissectic acid with atranorin, thamnolic acid with decarboxythamnolic acid, atranorin, barbatic acid, and acetylportentol; Chemical test in medulla are $\mathrm{C}-, \mathrm{K}+\mathrm{red}$, P+red. Habitat and ecology: In forest, this species was found on old and cracked bark, at altitudes ranging from $1640-1780 \mathrm{dpl}$, temperature is about $17,5^{\circ}-19^{\circ} \mathrm{C}$, humidity is about $85-98 \%$, and light intensity is about 600-1150 lux.

\section{Pachyphiale carneola (Ach.) Arnold}

This lichen belongs to Gyalectaceae family. Thallus dull green, thin, irregularly shaped, smooth, epruinose; chemistry: 4-0-methylphysodic acid, baeomycesic acid, lichesterinic acid, retigeric acid, and acetylportentol; apothecia lecidine, scattered, sessile, orbicular to oblong and irregularly shaped, margins with reddish brown, disc with reddish brown, up to $2 \mathrm{~mm}$ diam; spores 2-40 in each ascus, multiseptate, fusiform shaped, colourless, 6-8 $\mathrm{x} 0,5 \mu \mathrm{m}$; Chemical test in medulla are C+yellow, K+yellow, P+red. Habitat and ecology: In forest, this species was found on old and cracked bark, at altitudes ranging from $1640 \mathrm{dpl}$, temperature is about $18^{\circ} \mathrm{C}$, humidity is about $75-83 \%$, and light intensity is about $1650-1700$ lux.

\section{Pachyphiale sp.}


This lichen belongs to Gyalectaceae family. Thallus dull green, thin, irregularly shaped, smooth, it has reddish yellow soredia; chemistry: 4-0methylphysodic acid, acetylportentol, lichesterinic acid, baeomycesic acid, and retigeric acid; apothecia lecidine, scattered, sessile, orbicular to oblong and irregularly shaped, margins with brownish black, disc with brown, up to $1,2 \mathrm{~mm}$ diam; spores one in each ascus, multiseptate, fusiform shaped, colourless, 5-6 6 0,5 $\mu \mathrm{m}$; Chemical test in medulla are C-, K-, P-. Habitat and ecology: In forest, this species was found on old and cracked bark, at altitudes ranging from 1640$1780 \mathrm{dpl}$, temperature is about $17,5^{\circ}-18,5^{\circ} \mathrm{C}$, humidity is about $75-98 \%$, and light intensity is about 600-1700 lux.

\section{Lepraria sp.}

This lichen belongs to Stereocaulaceae family. Thallus grayish white, irregularly shaped, thin, pruinose, it has white soredia and reddish yellow isidia; chemistry: 4-0-methylphysodic acid, obtusatic acid, diffractaic acid, and acetylportentol; Chemical test in medulla are C+yellow, K+red, P+red. Habitat and ecology: In forest, this species was found on old and cracked bark, at altitudes ranging from $1640-1730 \mathrm{dpl}$, temperature is about $16^{\circ}-19^{\circ} \mathrm{C}$, humidity is about $85-98 \%$, and light intensity is about 475-1150 lux.

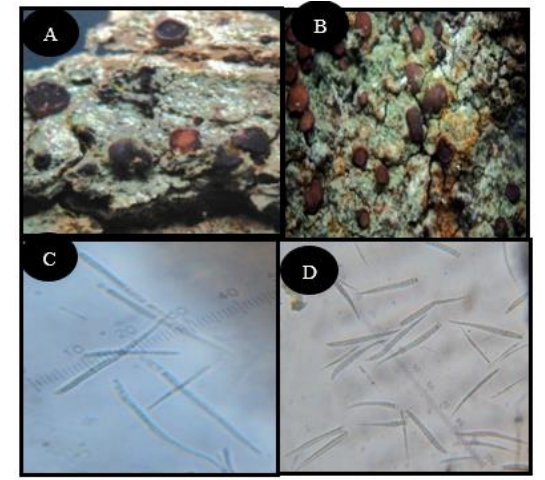

Figure 7. Thallus. A. Pachyphiale carneola; B. Pachyphiale sp.; Spores. C. P. carneola, D. Pachyphiale sp.

\section{Phlyctis agelaea (Ach.) Fw.}

This lichen belongs to Phlyctidaceae family. Thallus gray, thin, cracked or warted, irregularly shaped; chemistry: fumarprotocetraric acid, obtusatic acid, acetylportentol, and bellidiflorin; apothecia lecanorine, scattered, sessile, orbicular to oblong and irregularly shaped, margins with reddish orange, disc with green, green pruinose, up to $1,5 \mathrm{~mm}$ diam; spores $>2$ in each ascus, muriform, colourless, 4-7x 1-2 $\mu \mathrm{m}$; Chemical test in medulla are C+yellow, K+reddish yellow, P+red. Habitat and ecology: In forest, this species was found on old and cracked bark, at altitudes ranging from $1640 \mathrm{dpl}$, temperature is about $18,5^{\circ}$ $19^{\circ} \mathrm{C}$, humidity is about $83-85 \%$, and light intensity is about $1050-1150$ lux. 


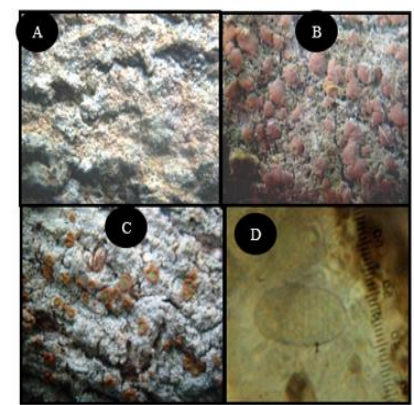

Figure 8. Thallus. A. Lepraria sp.; B. Lecania cyrtella; C. Phlyctis agelaea; Spores. D. Phlyctis agelaea

\section{Lecanora carpinea (L.) Vain.}

This lichen belongs to Lecanoraceae family. Thallus grayish green, thin, smooth or warted, irregularly shaped; chemistry: 4-0methylphysodic acid, baeomycesic acid and acetylportentol; apothecia lecanorine, scattered, sessile or adnate, roundish to irregularly shaped, margins with brownish gray, disc with pale black, reddish green pruinose, up to $2 \mathrm{~mm}$ diam; spores $4-9$ in each ascus, simple, colourless, $1 \times 1 \mu \mathrm{m}$; Chemical test in medulla are C+yellow, K+yellow, P+red. Habitat and ecology: In forest, this species was found on old and cracked bark, at altitudes ranging from 1640 $\mathrm{dpl}$, temperature is about $18^{\circ} \mathrm{C}$, humidity is about $75 \%$, and light intensity is about 1700 lux.

\section{Lecania cyrtella (Ach.) Th. Fr.}

This lichen belongs to Ramalinaceae family. Thallus grayish green, thin, smooth, not strongly attached on subsrate, pruinose, irregularly shaped; chemistry: baeomycesic acid, roccellaric acid, pseudo-norrangiformic acid and acetylportentol; apothecia lecanorine, scattered, sessile, roundish to irregularly shaped, margins and disc with brown, thalline margin which usually becomes excluded as the apothecia mature and become convex, up to $2 \mathrm{~mm}$ diam; Chemical test in medulla are $\mathrm{C}_{-}, \mathrm{K}-$, $\mathrm{P}-$. Habitat and ecology: In forest, this species was found on old and cracked bark, at altitudes ranging from $1640 \mathrm{dpl}$, temperature is about $18^{\circ} \mathrm{C}$, humidity is about $75 \%$, and light intensity is about 1700 lux.

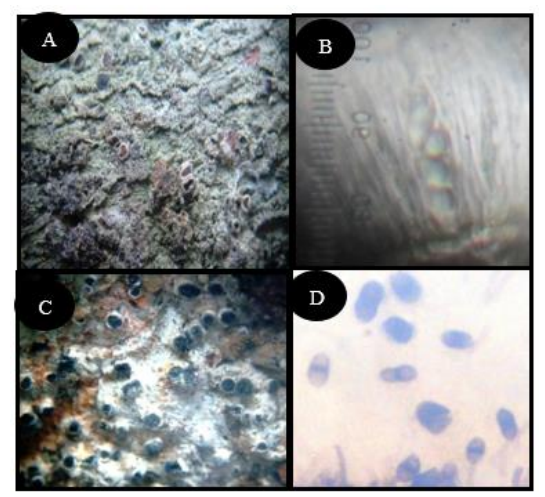

Figure 9. Thallus. A. Lecanora carpinea.; C. Cyphellium inquinans; Spores, $\quad$ C. $L$. carpinea; D. C. Inquinans

\section{Cyphellium inquinans (Sm.) Trev.}

This lichen belongs to Caliceaceae family. Thallus gray to reddish yellow, thin, warted, irregularly shaped, it has white and orange soredia; chemistry: norstictic acid, alectorialic acid and pseudo-norrangiformic acid; apothecia lecanorine, scattered, innate or sessile, roundish to irregularly shaped, margins with grayish white, disc with black, black pruinose, up to $1 \mathrm{~mm}$ diam; spores one septate, septate with black, brown, 1-3x $1 \mu \mathrm{m}$; Chemical test in medulla are C+yellow, 
Biotropic 2019. 3. (1): 1 - 12

Taxonomy Of Crustose Lichens In The Forest Of Tahura R. Soeryo, Batu, East Java

K+yellow, P+red. Habitat and ecology: In forest, this species was found on old and cracked bark, at altitudes ranging from 1640$1800 \mathrm{dpl}$, temperature is about $16^{\circ}-19^{\circ} \mathrm{C}$, humidity is about $75-98 \%$, and light intensity is about $450-1650$ lux.

\section{Unidentified}

Thallus grayish white, thin, warted, irregularly shaped; chemistry: fumarprotocetraric acid, dissectic acid with atranorin, roccellaric acid, pseudonorrangiformic acid, and acetylportentol; Chemical test in medulla are C+yellow, K+yellow, P+red. Habitat and ecology: In forest, this species was found on old and cracked bark, at altitudes ranging from 1640 $\mathrm{dpl}$, temperature is about $19^{\circ} \mathrm{C}$, humidity is about $85 \%$, and light intensity is about 1150 lux.

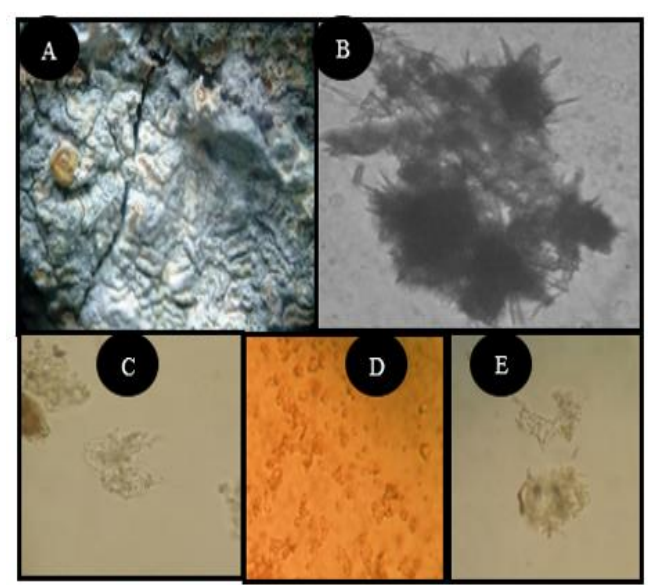

Figure 10. Thallus. A. Unidentified, B. Fumarprotocetraric acid, C. Pseudonorrangiformic acid, D. Acetylportentol, E. Roccellaric acid

\section{CONCLUSION}

In conclusion, new record of crustose lichen was collected for the first time in east java, which was discussed in this study. Twenty species of crustose lichens have been found and the family Graphidaceae is the most common with 8 species being identified. This research also found the new record species of Megalospora kalbii in Java.The results of this study are expected to be the basis for further lichen research and studies of the diversity of crustose lichen in other areas. All species were identified based on morphological, anatomical and chemical characteristics.

\section{ACKNOWLEDGEMENT}

The authors are thankful to Heru Cahyono who acted as field guide and informant during the survey. We also thank to thank parties for their assistance in the accomplishment of this research.

\section{REFERENCE}

Dayan, F.E. \& Romagni, J.G. 2001. Lichens as a potential source of pesticides. Pestic Outlook. 6: 229-232.

Dobson, F.S. 1992. Lichens An Illustrated Guide to The British and Irish Species. Singapore: Stamford Press.

Departemen Kehutanan. 2008. Taman Hutan Raya (TAHURA) R. Soeryo. Malang: UPT Taman Hutan Raya (TAHURA) R. Soeryo.

Eva, B. 2003. Lichen as Bioindicators of Forest Health, Biodiversity and Ecological Continuity, (Online), (eva.barreno@uv.es,). 
Hale, M.E. 1974. The Biology of Lichens. London: Edward Arnold Ltd.

Hale, M.E. 1969. How to Know the Lichens. United State of America : WM.c. Brown Company.

Hayward, B.W., Hayward, G.C., \& Galloway. 1975. Lichens From Northern Coromandel Peninsula, New Zealand.

Jannah, M, Rahayu, D.A, Mahadi, D.A, Saptasari, M., \& Untari, L. F.. 2009. The Diversity of Foliose Lichen in the Forest of TAHURA R Soeryo, Batu, East java. Proceding of the International Conference of Biological Science, Yogyakarta, tanggal 16-17 Oktober 2009.

Jannah, M, Rahayu, D.A, Mahadi, D.A, Saptasari, M., Lystiorini, D. \& Untari, L. F. 2010. The Diversity of Fructicose Lichen in the Forest of TAHURA R Soeryo , Batu, East java. Proceding of the International Conference of Assosiation Tropical Biology and Conservation, Bali, tanggal 19-23 Juli 2010.

Kenkel, N.C. \& Bradfield, G.E. 1986. Epiphytic Vegetation on Acer macrophyllum: A multivariate Study of Species-habitat Relationship. Vegetatio. 68: 43-53.

Negi, H.R. 2003. Lichens: A Valuable Bioresource for Enviromental Monitoring and Sustainable Development. General article: Resonance.

Nash, H.T. 1996. Lichen Biology. Arizona: Combridge University Press.

Negi, H.R. 2003. Lichens: A Valuable Bioresource for Enviromental Monitoring and Sustainable Development. General article: Resonance.

Rout, J., Pulakdas, \& Uperti, D.K. 2010. Epiphytic Lichen Diversity in a Reserve Forest in Southern Assam Northeast India. Tropical Ecology. 2: 281-288.
Richardson, D.H.S. 1992. Pollution Monitoring With Lichen. England: Richmond Publishing Co. Ltd.

Ramakantha, V., A.K., Gupta \& A. Kumar. 2003. Biodiversity of Northeast India: on overview. Envis Bulletin: Wildlife and Protected areas, Conservation of Rainforest in India.

Sipman, H.J.M. 1983. A Monograph of The Lichen Family Megalosporaceae. Vaduz: In der A.R. Gantner Verlag Kommanditgesellschaft.

Sipman, H.J.M. 1999. Revised Key to Megalosporaceae (genera Austoblastenia, Megaloblastenia, Megalospora, (Online), (www.megalospora.com).

Termina, M., \& Nevo, E. 2009. Lichen of Israel: Diversity, Ecology, and Distribution. Biorisk. 3: 127-136. 